\title{
Geochemistry of Li-enriched Zircon from the Napier Complex, East Antarctica
}

\author{
MAMI TAKEHARA ${ }^{1}$, KenJI HORIE ${ }^{1,2}, 58^{\text {TH }}$ JAPANESE \\ ANTARCTIC RESEARCH EXPEDITION GEOLOGICAL FIELD \\ SURVEY TEAM \\ ${ }^{1}$ National Institute of Polar Research, 10-3, Midori-cho, \\ Tachikawa-shi, Tokyo 190-8518, Japan. \\ takehara.mami@nipr.ac.jp \\ ${ }^{2}$ Graduate University for Advanced Studies (SOKENDAI), \\ 10-3, Midori-cho, Tachikawa-shi, Tokyo 190-8518, \\ Japan.
}

Zircon is one of the useful accessory-minerals for some geochronometers such as $\mathrm{U}-\mathrm{Pb}$ dating, and the concentrations and isotopic ratios of major and trace elements have been used as an indicator of the magmatic and metamorphic environment. The concentrations and the isotopic ratios of $\mathrm{Li}$ in zircon analyzed using secondary ion mass spectrometer (SIMS) provide useful information for the existence of liquid water in the early earth's surface and the contribution to felsic magma (e.g., [1]). We found extreme Li-enriched zircons ([Li]: $\sim 300-600 \quad \mathrm{ppm})$ in orthopyroxene-felsic-gneiss collected from the Harvey Nunatak within the ultrahightemperature metamorphism region in the Napier Complex, East Antarctica by the 58th Japanese Antarctic Research Expedition (JARE-58) Geological Field Survey Team. The zircons are characterized based on the concentration of the other trace element $(\mathrm{K}, \mathrm{Ca}, \mathrm{Mn}, \mathrm{Fe}, \mathrm{Al}, \mathrm{P}$, and rare earth elements(REE)) analyzed by a single-collector type sensitive high-resolution ion microprobe (SHRIMP-IIe) [2].

Some of the zircon grains collected from the Opx-felsic gneiss are hydrothermally altered because the zircons indicate high concentrations of non-formula elements such as $\mathrm{Ca}, \mathrm{Mn}$, $\mathrm{Fe}, \mathrm{Al}, \mathrm{K}$, and light REE. The altered zircon grains indicate lower Li concentrations than those of unaltered zircon grains. Oxygen isotope ratios $\left(\delta^{18} \mathrm{O}_{\text {vsmow }}\right)$ in the unaltered zircons indicate a mean of $4.93 \pm 0.09 \%$ and range from 4.31 to 5.34 $\%$. In the altered zircons, oxygen isotope ratios range from 1.97 to $5.78 \%$, which suggests that the oxygen isotope ratios in the zircons were modified by the hydrothermal fluid. Also, we will report the $\mathrm{Li}$ isotope ratios in the zircons in this presentation.

[1] Ushikubo et al. (2008) Earth and Planetary Science Letters, 272, 666-676. [2] Takehara et al. (2018) Chemical Geology, 484, 168-178. 